\title{
1 \\ What Is Bioethics? A Historical Introduction
}

\author{
HELGA KUHSE AND PETER SINGER
}

Since the 1960 s ethical problems in health care and the biomedical sciences have gripped the public consciousness in unprecedented ways. In part, this is the result of new and sometimes revolutionary developments in the biomedical sciences and in clinical medicine. Dialysis machines, artificial ventilators, and organ transplants offer the possibility of keeping alive patients who otherwise would have died. In vitro fertilization and related reproduction techniques allow a range of new relationships between parents and children, including the birth of children who are not genetically related to the women who bear them. The development of modern contraceptives, prenatal testing, and the availability of safe abortions have given women and couples increased choices about the number and kinds of children they are going to have. Groundbreaking developments in genetics and the possibility of genetic enhancement add a further dimension to these choices. Technological breakthroughs, however, have not been the only factor in the increasing interest in ethical problems in this area. Another factor has been a growing concern about the power exercised by doctors and scientists, which shows itself in issues about "patients' rights" and the rights of the community as a whole to be involved in decisions that affect them. This has meant greater public awareness of the value-laden nature of medical decision-making, and a critical questioning of the basis on which such decisions are made. It has become patently obvious during the past three or four decades that, to give just one example, someone has to decide whether to continue life-support for patients who will never regain consciousness. This is not a technical decision that only doctors are capable of making, but an ethical decision, on which patients and others may have views no less defensible than those of doctors.

It was in the climate of such new ethical issues and choices that the field of inquiry now known as "bioethics" was born. The word was not originally used in this sense. Van Rensselaer Potter first proposed the term for a "science of survival" in the ecological sense - that is, an interdisciplinary study aimed at ensuring the preservation of the biosphere (Potter 1970). This terminology never became widely established, however, and instead "bioethics" came to refer to the growing interest in the ethical issues arising from health care and the biomedical sciences. It is to bioethics in this latter sense that the present volume forms a Companion.

Although the term itself is new, and the prominence of bioethics owes much to recent developments in the biomedical sciences, bioethics can also be seen as a modern 
version of a much older field of thought, namely medical ethics. Undoubtedly, bioethics claims medical ethics as part of its province, but in many ways it takes a distinctly different approach. Traditionally, medical ethics has focused primarily on the doctor-patient relationship and on the virtues possessed by the good doctor. It has also been very much concerned with relations between colleagues within the profession, to the extent that it has sometimes seemed to exemplify George Bernard Shaw's remark that "all professions are conspiracies against the laity." Bioethics, on the other hand, is a more overtly critical and reflective enterprise. Not limited to questioning the ethical dimensions of doctor-patient and doctor-doctor relationships, it goes well beyond the scope of traditional medical ethics in several ways. First, its goal is not the development of, or adherence to, a code or set of precepts, but a better understanding of the issues. Second, it is prepared to ask deep philosophical questions about the nature of ethics, the value of life, what it is to be a person, the significance of being human. Third, it embraces issues of public policy and the direction and control of science. In all these senses, bioethics is a novel and distinct field of inquiry. Nevertheless, its history must begin with the history of medical ethics.

\section{Medical Ethics}

Medical ethics has a long and varied history (Reich 1995: 1439-646). While it is often thought that it had its beginning in the days of Hippocrates, in ancient Greece, it is in fact much older. Even tribal societies, without a written language, already had more or less well-articulated values that directed the provision of health care by shamans, exorcists, witches, sorcerers, and priests, as well as by midwives, bonesetters, and herbalists. One of the earliest written provisions relating to the practice of medicine is from the Code of Hammurabi, written in Babylon in about 1750 BC. It stipulates that if a doctor uses a bronze lancet to perform a major operation on a member of the nobility that results in death or leads to the loss of an eye, the doctor's hand will be cut off (Pritchard 1969). Other early provisions of medical ethics were embedded in a religious tradition. A monument in the sanctuary of Asclepius, for example, tells doctors to be "like God: savior equally of slaves, of paupers, of rich men, of princes, and to all a brother, such help he would give" (Etziony 1973); and the Daily Prayer of a Physician, often attributed to the twelfth-century Jewish doctor Moses Maimonides (but now thought to date from the eighteenth century), condemns not only "thirst for profit" but also "ambition for renown and admiration" (Veatch 1989: 14).

The ancient ethical codes were often expressed in the form of oaths. The best-known medical oath in the Western tradition is the Oath of Hippocrates, commonly assumed to be from the fifth century $\mathrm{BC}$, and often regarded as the very foundation of Western medical ethics. Despite the oath's continuing appeal, its origins are clouded in mystery. Around 500 BC many different schools of medical practice coexisted, each of them reflecting somewhat different medical, philosophical, and religious beliefs. One of these medical schools, on the island of Cos, was headed by the physician Hippocrates. The Hippocratic School produced a large body of writings on medicine, science, and ethics. The date of the oath, however, is unknown, with estimates ranging from the sixth century BC to the beginning of the Christian era (Edelstein 1967). The oath's significance 
in the history of Western medical ethics is twofold. In affirming that "I will use dietetic measures to the use and profit of the sick according to my capacity and understanding. If any danger and hurt threatens, I will endeavor to avert it," the oath establishes the principles of beneficence and nonmaleficence, that is, that doctors must act so as to benefit their patients and seek to prevent harm. In addition, the oath's prohibition on giving a potion to produce an abortion, or giving any poison to end the life of a patient, is consonant with the view of the sanctity of human life that has dominated medical ethics under Christendom. Other aspects of the oath - like the injunction to honor one's teacher like a parent, "to share his fate and if occasion arise supply him with the necessaries of life" - are less frequently referred to in modern discussions of medical ethics.

While some scholars hold that the increasing importance of the Hippocratic Oath is linked to the rise of Christianity, this is disputed by others who believe that there are significant differences and tensions in the ethical precepts on which Hippocratic and Christian medicine were built. One obvious difference lies in the two traditions' religious commitment. At different times, various modifications were thus introduced to make the Hippocratic Oath acceptable to Christians. One of the earliest of these dates from the tenth or eleventh century. It is entitled "From the Oath According to Hippocrates Insofar as a Christian May Swear it." This oath no longer required Christian doctors to swear to Greek gods and goddesses; rather, those taking the oath addressed themselves to "God the Father of our Lord Jesus Christ" (Jones 1924: 23).

Perhaps one of the most significant moral influences of Christianity relates to its emphasis on love for one's neighbor and compassion for the ill. Religious institutions, such as monasteries, began to set up "hospitals" for the ill and destitute, and Christian teaching emphasized that doctors must cultivate the virtues of compassion and charity. A treatise, probably dating from the early twelfth century, exhorts doctors not to heal "for the sake of gain, nor to give more consideration to the wealthy than to the poor, or to the noble than the ignoble" (MacKinney 1952: 27), and in the thirteenth century Thomas Aquinas considered it a sin if a doctor demanded an excessive fee, or if he refused to give gratuitous treatment to a patient who would die for want of it.

If greed and lack of charity were regarded as sins, so were other practices as well. Navarrus, a leading sixteenth-century canonist, provided a clear statement that condemned euthanasia as sinful, even if motivated by pity. In this, he followed St Augustine's earlier pronouncement, in The City of God, that Christians must not choose suicide to escape illness; and Thomas Aquinas' condemnation of the practice on the grounds that it was unnatural and a usurpation of God's prerogative to give and take life.

When it came to another topic still central to contemporary bioethical debate - that of abortion - the historical position of the Church has been somewhat ambiguous. While the practice was standardly condemned in the early Christian literature, its wrongness was often regarded as a matter of degree. Following Aristotle, various thinkers including Thomas Aquinas - thought that only the abortion of an animated fetus constituted homicide. Animation was presumed to occur at 40 days for male fetuses, and 90 days for female fetuses. By and large, this view remained dominant until 1869, when Pius IX declared all direct abortions homicide, regardless of the fetal stage of development. 
Over the millennia, many different religious groups have attempted to formulate the central virtues and duties of doctors in various ways, and to articulate their particular responses to issues within medical ethics. The Roman Catholic Church is thus not the only Christian Church to have well-developed views on a range of issues in medical ethics; there are a number of Protestant Churches with distinct positions as well. In addition, there are of course extensive non-Christian religious teachings. Jewish and Islamic medical ethics, for example, articulate the duties and responsibilities of Jewish or Islamic doctors, and in East Asia and the Indian subcontinent, traditions of medical ethics are intertwined with Taoism, Confucianism, Buddhism, Shintoism, and Hinduism.

Over the centuries, medical practitioners themselves continued to reflect on the qualities that the virtuous doctor should possess, in particular in his relationship with patients. While these reflections were typically intertwined with prevailing religious trends and teachings, the seventeenth and eighteenth centuries brought some changes. John Gregory, a prominent eighteenth-century Scottish doctor-philosopher, drew on prevailing Enlightenment philosophies to articulate his view that doctors must be "sympathetic," in the sense developed by the great Scottish philosopher David Hume. In other words, the doctor was to develop "that sensibility of heart which makes us feel for the distresses of our fellow creatures, and which, of consequence, incites us in the most powerful manner to relieve them" (Gregory 1817: 22).

Gregory's reflections on the role of doctors and the doctor-patient relationship are still highly relevant today. Not only was he possibly the first doctor who sought to develop a universal moral basis for medical ethics - one that was free from narrow religious and parochial concerns - but his view of the central role played by care and sympathy in the doctor-patient relationship may also be read as one of the first articulations of an "ethics of care." In recent times, care approaches to ethics have played an important role in feminist and nursing approaches to ethics.

\section{Nursing Ethics}

Medical ethics has not been the only source of ethics relating to health care. Professional nursing had its beginning in nineteenth-century England, where Florence Nightingale established the first school of nursing and laid down some of the ethical precepts that would shape the practice of nursing for a long time. Emphasis was placed on the character of the nurse. Above all else, a good nurse must be a good woman, as Florence Nightingale put it.

By the early 1890s nurses had begun seriously to discuss ethical issues in nursing. In 1899 the International Council of Nurses was established, professional journals, such as The American Journal of Nursing, sprang up and in 1901 Isabel Hampton Robb, a leader of nursing at the time, wrote one of the first books on nursing ethics, entitled Nursing Ethics for Hospitals and Private Use (Robb 1901). The vast majority of nurses are women and, until fairly recently, the vast majority of doctors have been men. Not surprisingly, the relationship between doctors and nurses reflected the different roles of women and men, and their relative status in society. One of the manifestations of this was the assumption that the primary responsibility of nurses was to doctors rather 
than to patients, and that nurses had to show absolute obedience to their medical colleagues. As one American nursing leader put it in 1917: "The first and most helpful criticism I ever received from a doctor was when he told me that I was supposed to be simply an intelligent machine for the purpose of carrying out his order" (Dock 1917: 394).

The view that the nurse's primary responsibility was to the doctor prevailed until the 1960s, and was still reflected in the 1965 version of the International Code of Nursing Ethics. Item 7 of the Code states: "The nurse is under an obligation to carry out the physician's orders intelligently and loyally." The revival of feminist thinking in the late 1960s paralleled the developing self-consciousness and self-assertiveness of nurses, and in the 1973 International Council of Nurses' Code for Nurses, the nurse's "primary responsibility" is no longer seen to be to doctors but to patients - "to those people who require nursing care."

This questioning by nurses of their traditional role and their relationship with doctors and patients eventually converged with a movement by feminist philosophers that challenged the traditional (and therefore male-dominated) view of ethics as a matter of abstract, impartial, and universal principles or rules. Instead of this conception of ethics, feminist philosophers like Nel Noddings (1984) conceived of ethics as a fabric of care and responsibility arising out of personal relationships. Building on this "female" approach to ethics, both philosophers and nurses sought to construct a new ethics for nurses based on the concept of care. Jean Watson, a nurse and a prominent proponent of a nursing ethics of care, applies to the nursing situation Noddings's view that an ethics of care "ties us to the people we serve and not to the rules through which we serve them" (Watson 1988: 2).

\section{Bioethics}

Perhaps the first "modern" work of bioethics was Joseph Fletcher's Morals and Medicine, published in 1954. Fletcher was an American Episcopalian theologian whose controversial "situation ethics" approach to ethical questions had more in common with consequentialist ethics than with traditional Christian views. In keeping with this, he later abandoned his religious belief. Although Fletcher did much to stimulate early discussions of ethical issues in medicine, it was only in the 1960s that bioethics really began to take shape as a field of study. This period was one of important cultural and social changes. The civil rights movement focused attention on issues of justice and inequality; the Cuban missile crisis and the Vietnam War led to a renewed questioning of war and nuclear weapons; and the resurgence of feminism, coupled with the availability of safe abortions and modern contraceptives, raised questions about women's reproductive rights. For much of the late 1960s and early 1970s, university authorities were besieged by students, initially in opposition to the Vietnam War, but later also demanding that their courses be relevant to the larger social issues of the day. These changes had their effect on the practice of philosophy too, sparking a renewed interest in normative and applied ethics. While the prevailing orthodoxy among English-speaking moral philosophers throughout the 1960s was that philosophy deals with the analysis of moral terms rather than with practical issues, this 
attitude began to shift in the 1970s. Increasingly, moral philosophers began to address themselves to such practical ethical issues as abortion and euthanasia, the ethics of war and of capital punishment, the allocation of scarce medical resources, animal rights, and so on. They frequently dared to question what had not been questioned before. Since some of these issues related to practices in health care and the biological sciences, this movement in philosophy helped to establish bioethics as a critical discipline.

The other major impetus to the growth of the field was the development of new medical technology that threw up questions no one had needed to answer before. One of the first high-profile bioethics issues in the United States shows this clearly. The first machines that could dialyze patients who had suffered kidney failure dramatically saved the lives of patients who would otherwise have been dead in a matter of days; but the machines were very expensive, and there were many more patients who were suffering from renal disease than there were machines. In 1962 the artificial kidney centre in Seattle, Washington, set up a committee to select patients for treatment. Its lifeand-death decisions earned it the name of "the God committee," and focused attention on the criteria it used. A study that showed a bias toward people of the same social class and ethnic background as the committee itself eventually led to further discussion about the best way to solve such problems.

Of all the medical breakthroughs of this period, the most widely publicized was the first heart transplant, performed by the South African surgeon Christiaan Barnard in 1967. The patient's death 18 days later did not dampen the spirits of those who hailed a new era of medicine - with its attendant ethical dilemmas. The ability to perform heart transplants was linked to the development of respirators, which had been introduced to hospitals in the 1950s. Respirators could save many lives, but not all those whose hearts kept beating ever recovered any other significant functions. In some cases, their brains had ceased to function altogether. The realization that such patients could be a source of organs for transplantation led to the setting up of the Harvard Brain Death Committee, and to its subsequent recommendation that the absence of all "discernible central nervous system activity" should be "a new criterion for death" (Rothman 1991). The recommendation has subsequently been adopted, with some modifications, almost everywhere.

If the availability of respirators and other powerful life-extending technology raised questions about the time when a patient should be declared dead, it also brought to the forefront questions about the proper limits of employing this technology in attempts to save or prolong a patient's life. While it had generally been accepted that competent patients must not be treated against their will, the situation of incompetent patients was far less clear. This was true not only with regard to patients who had been rendered incompetent by illness, accident, or disease, but also the treatment of seriously disabled or premature newborn infants. The question was simply this: if a patient is unable to say "no," does this mean that his or her life must always be prolonged for as long as possible, even if the patient's prospects are very poor?

In 1973 a leading US medical journal, the New England Journal of Medicine, published a study by two pediatricians on the ethical dilemmas they encountered in the special care nursery (Duff and Campbell 1973). The doctors, Raymond Duff and A. G. M. Campbell, did not think that all severely ill or disabled infants should receive lifeprolonging treatment. They thought it important to break down "the public and 
professional silence on a major taboo," and indicated that out of 299 infants in the special-care nursery, 43 had died as a consequence of a non-treatment decision. A central question was whether these non-treatment decisions were morally and legally sound.

Questions about the limits of treatment for those who are unable to decide for themselves were raised not only in the United States but in other countries as well. Australian and British doctors, for example, had begun publishing their views on the selective non-treatment of infants born with spina bifida, and thereby contributed to an ongoing debate about the appropriateness of a "quality of life" or a "sanctity of life" approach in the practice of medicine (Kuhse and Singer 1985).

It was not until 1976 that a landmark US case - that of Karen Ann Quinlan - lent support to the view that doctors had no legal duty to prolong life in all circumstances. Karen Ann Quinlan, who had become comatose in 1975, was attached to a respirator to assist her breathing. Her condition was described as "chronic persistent vegetative state." When the treating doctor refused to honor the family's wishes that Karen be removed from the respirator, the case eventually came before the New Jersey Supreme Court, which decided that life-support could be discontinued without the treating doctor being deemed to have committed an act of unlawful homicide. The case had implications for future thinking about various issues relating to medical end-of-life decisions, such as the moral and legal relevance of the distinction between so-called ordinary and extraordinary means of treatment, the role of parents or guardians in medical end-of-life decisions, the validity or otherwise of a now incompetent patient's previously expressed wishes regarding life-sustaining treatment, and so on.

Important ethical issues had already been raised in the United States with regard to the ethics of human experimentation by writers such as Henry K. Beecher (1966). It had become known that patients at the Jewish Chronic Disease Hospital in Brooklyn had been injected with live cancer cells, without their consent; that, from 1965 to 1971, mentally retarded children at Willowbrook State Hospital in New York had been inoculated with the hepatitis virus; and that a 1930 study aimed at determining the "natural history" of syphilis in untreated black men continued in Tuskegee, Alabama, until the early 1970s.

The public attention directed at these cases led to important changes in the scrutiny that US agencies henceforth directed at medical research. In 1973 the US Congress established the National Commission for the Protection of Human Subjects of Biomedical and Behavioral Research, whose members were charged with the task of drawing up regulations that would protect the rights and interests of subjects of research. While the Commission's role was only temporary, its influence was not. Most of the Commission's recommendations became regulatory law, and one of its reports - the Belmont Report - clearly articulated the ethical principles that should, in the Commission's view, govern research: respect for persons, beneficence, and justice. Subsequently, principles such as these have been influential in bioethics through their incorporation into a widely used bioethics text, now in its sixth edition - Principles of Biomedical Ethics (Beauchamp and Childress 2009).

By the end of the 1960s, mounting ethical problems in medicine, research, and the health-care sciences had already led to the establishment in the United States of the first institutions and centers for bioethics. One of the best known of these centers - the Institute of Society, Ethics and the Life Sciences (the Hastings Center) - was founded 
by Daniel Callahan and Willard Gaylin in 1969, and its publication, the Hastings Center Report, was one of the first publications exclusively directed toward the newly emerging discipline of bioethics.

Almost from the beginning, bioethics was an interdisciplinary enterprise. While ethics had been the near-exclusive domain of moral philosophers and religious thinkers, bioethics crossed the boundaries not only of medicine, nursing, and the biomedical sciences, but of law, economics, and public policy as well. Bioethics in this broad, interdisciplinary sense has since become firmly established as a field of inquiry and of learning - first in the United States, and since then in many other countries as well. It is now taught at universities at both undergraduate and postgraduate levels, and many nursing and medical schools regard bioethics as an integral part of their curriculum. Today there are many bioethics research centers throughout the world, and bioethicists are often consulted by government commissions, law reform bodies, and professional organizations. Many countries have their own national bioethics associations and the International Association of Bioethics (IAB) links bioethicists from all parts of the world. A number of highly regarded scholarly bioethics journals emanate from different continents, and international congresses on bioethics are now a frequent phenomenon. In short, while bioethics had its beginning in the United States, it is now a global field of inquiry.

Bioethics is now also becoming more global in its focus. As Michael Selgelid points out in his contribution to this volume (chapter 36), 90 percent of medical research resources are spent on diseases that account for only 10 percent of the global burden of disease - the diseases that people in rich countries are likely to suffer from. This is in part because pharmaceutical corporations have no incentive to develop drugs to treat people who will not be able to afford to buy them, and in part because the government research funds of rich nations are also mostly directed toward finding treatments for the diseases that afflict the citizens of those nations. There is, therefore, comparatively little research into finding treatments for the diseases from which people in poorer nations are likely to suffer. That fact itself, of course, poses an ethical question - do the people of the rich nations, through their governments or through private philanthropy, have an obligation to reverse this imbalance? Bill and Melinda Gates clearly believe there is. The website of the Gates Foundation says that one of their key values is "All lives - no matter where they are being led - have equal value" and the research they are funding is directed against diseases like malaria, which kill millions of people every year, virtually all in developing countries.

But there has also been a 10/90 problem in bioethics itself - in fact, until the 1990s, probably much less than 10 percent of the work of bioethicists was focused on bioethical issues raised by 90 percent of the global burden of disease. This is now changing. Developing World Bioethics, a journal devoted to bioethical issues relating to the developing world, is one example of this change. The IAB has made a deliberate effort to encourage bioethics in developing countries. As discussed elsewhere in this volume, much more attention is being paid to bioethical issues raised by infectious diseases, including, but not limited to, HIV/AIDS. In this revised edition, we have also increased the number of articles dealing with global bioethical issues and issues that particularly face developing countries. It remains true, unfortunately, that the majority of articles dealing with specific issues focus on bioethical issues in affluent countries. That 
reflects the state of the field today - although it is moving in the right direction, as far as increasing its focus on problems outside affluent nations is concerned, it is moving slowly and there are still very few people working in bioethics in developing countries, and writing about the issues those countries face.

\section{References}

Beauchamp, T. L. and Childress, J. F. (2009) [1979]. Principles of Biomedical Ethics, 6th edn. New York: Oxford University Press.

Beecher, H. K. (1966). Ethical and clinical research. New England Journal of Medicine 274: $1354-60$.

Dock, S. (1917). The relation of the nurse to the doctor and the doctor to the nurse. American Journal of Nursing 17.

Duff, R. S. and Campbell, A. G. M. (1973). Moral and ethical problems in the special-care nursery. New England Journal of Medicine 279: 890-4.

Edelstein, L. (1967). The Hippocratic Oath: text, translation and interpretation. In O. Temkin and C. L. Temkin (eds.), Ancient Medicine: Selected Papers of Ludwig Edelstein. Baltimore, MD: Johns Hopkins Press, pp. 3-63.

Etziony, M. B. (1973). The Physician's Creed: An Anthology of Medical Prayers, Oaths, and Codes of Ethics Written by Medical Practitioners Throughout the Ages. Springfield, IL: Charles C. Thomas.

Fletcher, J. (1954). Morals and Medicine: The Moral Problems of the Patient's Right to Know the Truth, Contraception, Artificial Insemination, Sterilization, Euthanasia. Boston: Beacon.

Gregory, J. (1817). Lectures and Duties on the Qualifications of a Physician. Philadelphia: M. Carey. Jones, W. H. S. (1924). The Doctor's Oath: An Essay in the History of Medicine. New York: Cambridge University Press.

Kuhse, H. and Singer, P. (1985). Should the Baby Live? The Problem of Handicapped Infants. Oxford: Oxford University Press.

MacKinney, L. C. (1952). Medical ethics and etiquette in the early Middle Ages: the persistence of Hippocratic ideals. Bulletin of the History of Medicine 26: 1-31.

Noddings, N. (1984). Caring: A Feminine Approach to Ethics and Moral Education. Berkeley: University of California Press.

Potter, V. R. (1970). Bioethics, science of survival. Biology and Medicine 14: 127-53.

Pritchard, J. B. (1969). Ancient Near Eastern Texts Relating to the Old Testament, 3rd edn. Princeton, NJ: Princeton University Press.

Reich, W. T. (ed.) (1995). Encyclopedia of Bioethics. London: Simon \& Schuster and Prentice Hall International.

Robb, I. H. Hampton (1901). Nursing Ethics for Hospitals and Private Use. Cleveland, OH: J. B. Savage.

Rothman, D. (1991). Strangers at the Bedside. New York: Basic Books.

Veatch, R. M. (1989). Medical Ethics. Boston: Jones and Bartlett.

Watson, J. (1988). Introduction: an ethic of caring/curing/nursing qua nursing. In J. Watson and M. A. Ray (eds.), The Ethics of Care and the Ethics of Cure: Synthesis in Chronicity. New York: National League for Nursing. 
